\title{
TANITMA: Ersen ERSOY, Ümran AY, Hoca Dehhânî Divant, Türkiye Bilimler Akademisi, Ankara 2017, 303 s.
}

\section{Fatih BAŞPINAR'}

Hayatı hakkında çok az bilginin bulunduğu, hatta hangi asırda yaşadığı bile tam olarak tespit edilemeyen Hoca Dehhânînnin 1 kaside ve 7 gazelden başka elde şiirleri bulunmamaktaydı. Hayatı ve edebî şahsiyeti hakkında verilen bilgi ve varılan kanaatlerin bir kısmı bu az sayıdaki şiire dayanıyordu.

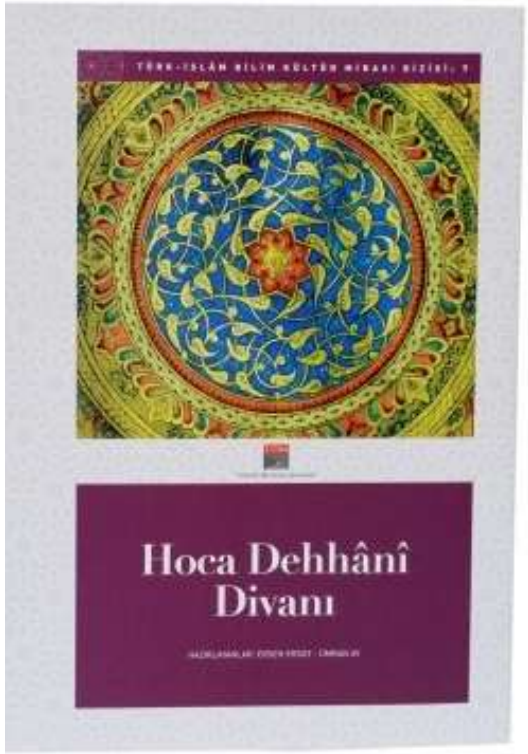

2017 yllının yaz aylarında neşredilip okuyucular ve araştırmacıların istifadesine sunulan Hoca Dehhânî Divanı, Kütahya Dumlupınar Üniversitesinden Doç. Dr. Ersen ERSOY ve Marmara Üniversitesinden Doç. Dr. Ümran AY'ın ortak çalışması. Neşrini merakla beklediğimiz divan hakkında araştırmacılar Divan Edebiyatı Araştırmaları Dergisìnin 15. sayısında (2015) Hoca Dehhânî Hakkında Yeni Bilgiler adıyla bir makale yayımlamışlardı. Bu makale ile araştırmacıların ilim âlemine sundukları yeni bilgiler kısaca şöyleydi:

1. Dehhânî’nin yeni şiirleri Medine Arif Hikmet Bey Kütüphanesi'nde Mecmua-ı Devâvîn adıyla 251/811 numarada kayıtlı bir divan mecmuası içinde yer almaktadır ve 2 kaside ile 97 gazelden ibarettir. Dolayısıyla Dehhânîye ait şiirlerin toplamı 2 kaside ve 104 gazele ulaşmıştır.

2. Dehhânî 14. asrın ilk çeyreğinde dünyaya gelmiş ve bir kasidesinde adı geçen Karamanoğlu Alâeddin Alî Bey (ö.1398) zamanının hiç olmazsa bir kısmını idrak etmiştir. Şeyhoğlu Mustafa, Ahmedî, Ahmedi Dâî gibi şairlerle çağdaştır.

3. Şair sadece din dışı şiirler söylememiş, muhtevası tevhid ve münacat olan ve yer yer tasavvufi unsurlarla bezeli şiirler de kaleme almıştır.

Araştırmacıların yeni şiirlerden birkaç örnek de yayımladıkları bu makaleden sonra Hoca Dehhân Divanı'nın neşredilmesi için iki yıl daha beklemek gerekti. Fakat artık Dehhânîye ait yeni şiirleri -hem de itinalı bir baskı ile- okuma imkânına kavuştuğumuza göre beklemeye değdi diyebiliriz. Zira Türkiye Bilimler Akademisi'nin Türk-İslâm Bilim Kültür Mirası Dizisinin 7. kitabı olan divan, beyaz kâğıda, renkli, ciltli ve gömlekli olarak özenli bir baskı ile neşredilmiş. 15. sayfada Önsöz ile asıl kısmı başlayan çalışmanın Giriş bölümünde önce Hoca Dehhânî hakkında daha evvel yapılan araştırmalarda ortaya konan bilgiler üzerinde durulmuş, ardından şairin hayatı, eserleri ve edebî kişiliği hakkındaki yeni bilgiler sıralanmıştır. Bu yeni bilgiler araştırmacıların daha önce neşrettikleri makalede verdikleri ve bizim de yukarıda kısaca değindiğimiz bilgiler istikametindedir.

Divan'ın incelenmesine ayrılan ikinci bölümde önce şiirler şekil yönünden ayrıntılı bir biçimde ele alınmıştır. Burada divanın tertip şekli, içinde yer alan nazım şekilleri ve şiirlerin beyit sayıları üzerinde durulmuştur. Ardından Dehhânı̂’nin kullandığı redif ve kafiyelerin ayrıntılı bir biçimde ele alındığını

Konya Necmettin Erbakan Üniversitesi, Fen Edebiyat Fakültesi, Türk Dili ve Edebiyatı Bölümü, fbaspinar@gmail.com [Tanıtma yazısı kayıt tarihi: 5.4.2018-kabul tarihi: 14.4.2018] 
görüyoruz. Edebî Sanatların incelendiği kısımda Mecazlar alt başlığı altında teşbih, istiare, teşhis, tevriye, tekrir, mübalağa, hüsn-i talil, telmih, leff ü neşr, tenasüp tezat, nidâ, istifham, tecâhül-i ârif, irsâl-i mesel, iktibas; Söze Dayalı Edebî Sanatlar alt başlı̆̆ıla ise cinas, iştikak, musammat, tarsi ve cemin Dehhânî'deki kullanılışına örnekler verilmiş ve bahse konu sanatların diğer örnekleri de listelenmiş. Bu kısmın başında araştırmacılar, Dehhânî’nin sormak fiilini şiirlerinde daima tevriyeli kullandığını özellikle zikrediyorlar.

Divan'ın Muhteva Yönünden İncelenmesi kısmında Atasözleri ve deyimler, Tabiat; Eşyâlar, Giyimkuşam ve yeme-içme kültürü; Dinî ibareler, Kişiler, Yer isimleri, Arkaik kelimeler başlıklarını görmekteyiz. Bundan sonra eserin imla özellikleri aktarılarak yaklaşı 45 sayfa kadar süren Giriş ve İnceleme bölümleri sona erdirilmiştir.

Transkripsiyonlu olarak ve yazmadaki siraya göre verilen Metin bölümüne göre Hoca Dehhânînin şiirleri 2 kaside, 104 gazel (7'si daha önceden bilinen, 97'si bu çalışmaya ortaya konan) olmak üzere 106 parçadan müteşekkildir. 132. sayfada sona eren şiirlerden sonra Kaynaklar bölümü yer almakta. Ardından eseri okuyanlara yardımcı olması gayesiyle hazırlandığı anlaşılan bir küçük sözlüğe yer verilmiş. Ancak bu kısmın daha geniş olması gerektiği kanaatini de belirtelim. Şiirlerin matla beyitlerinin kafiye harflerine göre sıralandığı Matlalar Dizini eserden istifade etmeyi kolaylaştırdığı için son derece faydalı bir ek olmuş. Eski Türk Edebiyatı sahasında yapılan metin neşri çalışmalarında az sayıda rastladığımız Dizin ise kitabı daha da zenginleştirmiştir diyebiliriz. Kitabın zenginliğini üst noktaya taşıyan ise çalışmanın sonuna eklenen ve Medine Şeyhülislam Arif Hikmet Bey Kütüphanesinde bulunan yazmanın renkli tıpkıbasımı.

Bütün bu bölümleriyle Hoca Dehhânî Divanı, Türkçe ve klasik Türk edebiyatı için kıymetli bir çalışma olarak önümüzde durmakta. Bununla beraber eseri okurken dikkatimizi çeken ve düzeltilmesi gerektiğini düşündüğümüz hususlara burada işaret edeceğiz.

\section{Metnin okunmasına dair teklifler}

Hoca Dehhânî Divanı başarılı bir metin aktarımı çalışmasının ürünü olarak elimizde bulunuyor. Bununla beraber metnin yalnızca iki yerinde yanlış değerlendirildiğini düşündüğümüz okumalar bulunmaktadır. Bunlardan ilki:

\section{Yandı Dehhânî firâkuñ odına}

Dimedüñ oda yanaram kandasin (G.30/7)

beytinde geçen yanaram kelimesindedir. Gazelin kafiyeleri nigârum-çenârum, gül-‘zârum, müşkbârum, bahârum, lâlezârum, yârum şeklinde gelirken makta beytinde kafiye kelimesi Türkçe çekimli bir fiil olan yanaram kelimesi olmuş. Halbuki yanarum olmalıydı. Zira beyitte "Dehhânî senin ayrılık ateşine yandı, fakat sen 'Ey ateşe yananım, nerdesin?' demedin.” denmektedir. Dolayısıyla kelime yanaram şeklinde geniş zamanda çekimlenmiş bir fiil olarak değil, "yanan" anlamında isim olan yanar olarak düşünülmeli ve sonu iyelik ekiyle tamamlanarak yanarum diye okunmalıydı.

Divandaki 74. gazelin:

Şâhâ beni fürkat odına niçe yakasın

Ya bilişüñi yâd idüben ya da yakasın (G.74/1) 
şeklindeki matla beytinin ikinci mısraına bu hâliyle mana veremedik. Yakasın kelimeleri şair tarafından kafiye olarak alındığına göre tekrar eden bu kelimelerin redif olmaması için cinaslı olması icap eder. $\mathrm{Bu}$ bakımdan ikisinin anlamları birbirinden farklı olmalı. Yakmak fiilinin bildiğimiz anlamı dışında bir de 'yaklaşmak, yaklaştırmak' manaları mevcut. Dolayısıyla şairin ikinci mısrada kastettiği mana bu olmalı. Fakat "Ey şah, beni ayrılık ateşine daha ne kadar yakacaksın? Yahut tanıdık kimseyi anıp yahut yaklaşacaksın?” şeklinde nesre çevirdiğimiz beytin manası bu hâliyle de vuzuha kavuşmuyor. Beyti:

Şâhâ beni fürkat odına niçe yakasin

Ya bilişüñi yad idüben yada yakasın

şeklinde okursak kanaatimizce şairin kastı açığa çıkıyor. Dehhânî "Ey şah, beni ayrılık ateşine daha ne kadar yakacaksın? Ve daha ne kadar tanıdığını yabancı görüp yabancıya yaklaşacaksın?” demektedir.

\section{İmla yahut transkripsiyonla ilgili düzeltme teklifleri}

Çalışma içerisinde hem inceleme hem de metin bölümünde gözümüze çarpan imla ve transkripsiyon hataları ile bunların olması gereken yazılışları şu şekildedir:

\begin{tabular}{|c|c|}
\hline āşıłḳa: & ‘āşılḳa G.84/3. \\
\hline bade: & bāde G.79/1. \\
\hline dār u beḳā: & dār-1 beḳā (69. s.) \\
\hline didim-ise: & didüm-ise G.7/6. \\
\hline dutasun: & dutasin K.1/18. \\
\hline garra: & girra G.81/4. \\
\hline gerindium: & gerundium (6o.s.) \\
\hline ḥaĕrā-pūş: & haḍ̂rā-pūş G.3/12. \\
\hline Ḥıżr: & Hiżr G.3/12. \\
\hline ḩār: & hvāā G.11/4. \\
\hline Ken`an: & Ken‘ān G.31/3, G.98/5 \\
\hline Ken’ān: & Ken‘ān G.33/1. \\
\hline Rıĕvān: & Riḍvān G.70/4. \\
\hline țāş: & țaş G.65/5. \\
\hline şem²: & şem` G.101/5. \\
\hline
\end{tabular}

\section{Deyimler ve kalıplaşmış sözlere dair}

Eserin bu bölümünde (51. s.) tespit edilebilen 8 atasözü ile deyimler ve kalıp ifadelere liste hâlinde yer verilmiştir. Ancak deyimlerin açıklamalarına yer verilmediği belirtilirken "eserin nesre çevirisi yapıldığı için” şeklinde bir ibare geçmektedir. Fakat eserin nesre çevirisi yoktur. Divan içinde geçen deyimler ve kalıplaşmış sözlerden araştırmacıların gözünden kaçtığını düşündüklerimiz bulunmaktadır. Bunlardan Deyimler ve kalıp ifadeler içinde hiç yer verilmeyenler şöyledir:

el yumak K.2/11, G.97/1

işitmeze gelmek G.13/6 (krş. sözü işitmeze urmak G.13/6, G.21/2) 
BOOK REVIEW: Ersen ERSOY, Ümran AY, Hoca Dehhânî Divanı, Türkiye Bilimler Akademisi, Ankara 2017, 303 s / F. Başpınar (p. 311-315)

ele girmek/ girmemek G.24/2, G.47/4, G.75/6, G.84/4

derde düşmek G.31/3

yüzini kızartmak G.32/4

özini unutmak G.39/3

gam yememek G.40/7, 94/8

oda yakmak G.47/1, G. 68/3, G.96/2

kulağını burmak G.51/2

(aşk) od(ın)a yanmak G.52/2 (bkz. oda yanmak)

ta'na urmak G.4O/2, G.56/3, G.69/6

oda yanmak G.6o/5

dilini bağlamak G.64/9

laf urmak G.71/1

dilini uzatmak G.79/4

gönül yıkmak G.81/4

sözde kll yarmak G.84/6

ayağı izi tozına baş urmak G.88/3 (krş. ayağı (tozu)na yüz vurmak G.73/2, G.92/6)

bağrı kebâb olmak G. 91/3

(hecr) od(In)a yanmak G.94/5 (bkz. oda yanmak)

bâda virmek G.96/2 (bkz. yile virmek )

yüz suyı G.86/2

işi zer (altun) olmak G.99/9

özini yire urmak G.103/1

gönülden çıkarmak G.103/7

Deyimler ve kalıp ifadeler içinde yer verilip eksik bırakılan örnekler ise tespit edebildiğimiz kadarıyla şunlardir:

yüz döndermek G. 65/7

dil uzatmak G.72/3

hâtırı cem‘ olmak G.83/2 (bkz. hâtırı cem‘ kılmak G.20/7)

yüz urmak G.92/1

gussa yimek G.92/3

yüz çevirmek G.93/3 (bkz. yüz döndürmek G.66/2)

kanını toprağa karmak G.100/5.

Bütün bunlardan başka çalışmanın Dizin bölümünde dağıt-/tağıt-, eyit-/ayt-/eyt-, gözel/güzel i/î/iy gibi farklı imlalara sahip aynı kelimeler arasında birbirine gönderme yapılmasının dizini daha faydalı hâle getireceği kanaatindeyiz. Son olarak 14. asır klasik Türk şiirinin önemli şairlerinden Dehhânîye ait şiirleri başarılı bir çalışma ile ilim âlemine sunduklarından ve Hoca Dehhânî Divanı'ndan hareketle 
TANITMA: Ersen ERSOY, Ümran AY, Hoca Dehhânî Divanı, Türkiye Bilimler Akademisi, Ankara 2017, 303 s / F. Başpınar

yapılacak yeni çalışmalara kapı araladıklarından dolayı araştırmacılar Ersen ERSOY ve Ümran AY’a müteşekkir olduğumuzu belirtmeliyiz. 